\section{SJESR}

Sir Syed Journal of Education \& Social Research

\title{
The Transgenders' Segregation in Khyber Pakhtunkhwa (Pakistan) with Special Focus on their Inaccessibility to Higher Secondary / Higher Education
}

\author{
* Dr. Tariq Mehmud, Deputy Registrar \\ ** Mr. Abdullah, Lecturer \\ *** Dr. Muhammad Idris, Assistant Professor
}

\begin{abstract}
Transgender is a comprehensive and inclusive term. This term separates and divides those people whose gender manifestation does not have any correspondence and resemblance with their gender identification at the time of their birth. This research article focused on the issues of transgenders with the special focus on their inaccessibility to education. The transgenders residing in Khyber Pakhtunkhwa (KP) feel themselves in a pit of infamy. The objectives of this article were to discover the hurdles and barriers faced by transgenders in KP not only in their day to day life but also in their inaccessibility to education.

The transgenders of the District Mardan (the second biggest city of KP) was the population of the study. The Chain referral sampling technique was adopted because the population of the study was not easily accessible. The sample of 20 participants was selected and it comprised of two teachers, two lawyers, two trans parents and fourteen transgenders. The thematic interpretation and analysis revealed that transgenders faced hurdles and scathing attitude in every walk of life especially in their access to education. The main reason behind their plight is the lack of knowledge among the common masses regarding the status and rights of transgenders in the Islamic state of Pakistan. This article is an eye-opener for all the social circles / organizations and NGO's not only nationally but also globally.
\end{abstract}

Keywords: Transgenders' Education, KP

\section{Introduction}

Gender identity is very vital for being male or female. Sense of gender and morphology of a human body, both are different, each develops at different times, at different stages in human structure (vitale, 1997). In Muslim societies there are five types of gender manifestation.
(i). eunuch (khasi)
(ii). hijrah
(iii). the mukhannath
(iv). the mamsuh
(v). the khuntha

\footnotetext{
* Abdul Wali Khan University Mardan Email: mehmudawkum@gmail.com

** Government College of Management Sciences and Commerce, Mardan Email: pdsabdullah@gmail.com

** Department of Education, Abdul Wali Khan University Mardan Email: midrees@awkum.edu.pk
} 
Khasi (eunuch) is unman male. They were assigned the duties of guarding the harem as treasure to king in Middle East and China (Nolon, 2009). Khasi is a person who has male sex organs and is reared as boy until castraction - mostly by imputation off testicles. This is an in-between status i.e. neither male nor female (Kugle, 2010, Marmon, 1995).

Hijrahas are those who adopt female qualities and traits after being born as boys. This practice of imputation of testicles has been in fashion in many countries of South Asia. They are basically the imitators of female peculiarities and traits. They are considered neither male nor female (O’ Brein, 2008, Nanda, 1999).

The Mukhannath is the one who tries to be like a female by copying the female traits such as softness of voice and speaking style (Rowson, 1991).

Mamsuhs are those who do not have adequate and sufficient male or female external reproduction organs (Karimini, 2010).

Transgenders have been the important part of human society and history. They were greatly honored and assigned with the important responsibilities by the past Mughal rulers. Due to this great honor by the rulers, many non-muslim trans people reverted to Islam. The Prophet Muhammad (SWA), the last and final messenger of Allah, treated them honorably and with high regard and esteem. During Hajj (Pilgrimage) they were facilitators and communicators between male and female pilgrims. The Prophet Muhammad (SWA) advised to treat the transgenders with care, love and kindness. This belief also prevailed that transgenders were closer to God (Allah), so the Mughal and Ottoman rulers appointed them as ministers and intelligence chiefs. They had greater and more power and dignity than most of the important and powerful ministers.

In 1871, the British government in India, passed an Act of criminal tribes. Transgenders were also included in the list of criminal tribes. Due to this Act, the transgenders lost and deprived of their dignity and high respect (Hoda, 2010).

The British always considered and declared them a 'danger' to society (CSS Forum, 2010).

After the imposition of the Act of criminal tribes, the transgenders had to strive for their survival and they started doing different practices and errands. Some of them became dancers and merry makers at the birth of children and at wedding ceremonies etc. and earned money and means for their square meals and shelter. 
In Pakistan, especially in KP (the Pashtoon majority province of Pakistan), these trans people do not have an easy and smooth access to education. Therefore, they are not properly educated and trained for respectable living and jobs.

The researchers of this article were very keen and inquisitive about the issues of transgenders in KP (Pakistan). KP being near to Afghanistan does not have any welcoming and inviting incentives for transgenders. The social, economical and educational conditions of transgender in KP is deplorable and pathetic they are open victims of moral, social and sexual harassment in every field of life. They are encountered with chronic issues of health, education and residential. They are always under the fatal threads of honour and life from all the rank and file. People have the concept regarding them that they are deprived of all the basic rights. Majority of transgender are sparing, shameful and disguisting lives. They are residing in unhygienic locations where there is scarcity of basic needs of life such as sanitations, electricity and health facilities. The posh area are out of bond for their living. Transgender are having, depleted issues related with education in colleges and Universities they are victims of bullying and sarcastic remarks of fellows. The jaundiced attitude of teachers is adding fuel to the fire. They have been charged in humanly in residential rents. They are passing secluded life. There is no quota in universities for providing education to them in Pakistan with special reference to KP province. The killing and humiliation of transgenders have become the fashion of the day in KP which are totally against the divine teachings. These transgenders are also found in those activities which are objectionable both religiously and culturally. Furthermore, these transgenders do not have any access to respectable and acceptable professions and jobs. These problems have their roots in the culture not in the religion of the territory / area.

According to whittle, Turner and Al-Alami (2001), "these trans people faced discriminatory behavior and attitude not only from their fellows but also from teaching faculty in the schools of the United Kingdom".

"In Northern Ireland, the trans people are not aware of their gender identity (MC Bride, 2013).

"In Northern Ireland's Schools, the trans people feel anxiety, stress and discomfort and due to this they become truants (Wiley and Harnich-fegar 1974, Buscha and Conte, 2014). 
At present in Pakistan, the transgenders have been ignored and they have been deprived of basic civic and social facilities and gatherings. They live in colonies like slum areas being looked after by guru (leader).

They only seem to be survived by begging, sex work and dancing at celebrations (Tufail, 2006).

The conditions have become more and more miserable for them. Although the Supreme Court of Pakistan in December 2009 has secured their rights of identity and jobs but no obvious improvement has been seen yet (Ashraf, 2010). They were also pledged for their gender equality by 2015 by the United Nations but nothing has been done so far.

\section{Research Methodology}

\section{Objective of the Study}

To know about the issues of the transgenders with the special focus on their inaccessibility to education.

\section{Research Design}

The survey research design was approved and selected by the researchers of this research article.

\section{The Area of the Study}

District Mardan (the second biggest city of KP) was selected as the area of the study.

\section{Sample of the Study}

The chain sampling technique was adopted in which the participants contributed with the researchers in finding out other similar respondents / participants. The sample comprised of 20 participants. The sample had two teachers, two lawyers, two trans parents and fourteen transgenders.

\section{Research Tool}

With the help of questionnaires (a self-semi structured guidelines) the data was collected from the sample of the study.

\section{Data Collection}

The data was collected by the researchers themselves from the participants with the help of informants. The researchers are teachers at different levels so the researchers selected informants from their students.

\section{Data Analysis}

The data were analyzed thematically in the light of the items given in the questionnaire. The respondents were lawyers, teachers / school heads / transparent and trans themselves. 


\section{Lawyers}

The prominent lawyers were selected and their responses to different questions were recorded thus;

a. Their responses regarding the status of trans in Pakistani law were that in 20018 Pakistani parliament passed an act regarding the rights of trans.

b. Regarding the implementation of the law the lawyers were of the view that some facilities and safety from law are there but much more is yet to be done especially creating awareness among the dwellers of the society so that their rights are fully protected and safeguarded.

c. Regarding the suggestions from the lawyers' point of view, they shared their views that these trans must be accepted and accommodated by the society in all forms and shapes of society like common and normal citizens of the society.

d. Regarding the trans as their colleague in the court, their response was negative as there was no one among the lawyers from trans community. But the honorable lawyers were fully supportive and wanted to see positive and pleasant changes in the life of the trans.

\section{Teachers/School Heads}

The two local teachers who had full knowledge about the trans were engaged for data.

a. Their response about the presence of trans in the schools were mixed. They were of the view that they had trans in their schools but they are humiliated and teased not only by society but also by their own parents and family members, therefore, they become truant and leave the schools.

b. They are not encouraged and motivated as virtually they are not accepted by the society, if they are encouraged by teachers for a short while that is not enough. The society as a whole accept them.

c. These hurdles are removed by the teachers inside the premises of the schools but the society as a whole not accommodative for them, therefore, the teachers' struggles in this regard remain useless.

d. There are black sheep in every society, sometimes some of the teachers and their fellow students force them for adultery and fornication. This sexual harassment is one of the major causes which hamper them from getting education for a specific period of time. 
e. The teachers suggested that first of all they should be accepted and owned by their own parents in the literal sense and if they are honored and protected by their own respective families, then, movement in all walks of life may become easy, smooth and respectable for them.

f. The teachers were not in favor of separate schools for them as their strength is not that much sufficient for the establishment of separate schools for them and as Pakistan is not that much economically sound and it can't afford such a luxury.

\section{Parents}

a. The parents responded to the questions with heavy hearts ant they consider these trans impotent and useless. They behave like female and this a source of degradation for the parents as the Pakhtun society doesn't consider them respectable and so as their parents.

b. The parents of the trans consider them innocent and stress that they need great care and attention but what about the society, the society is not welcoming for them. These trans know nothing but only dancing and this is considered obscenity and so it makes them unacceptable to the society and the parents are also from the same society.

c. The parents know that their present condition is not by choice on their part. They have got no 'say' in their making and forming but due to the ill-treatment of the society, the parents don't own them fully and try to get rid of them by pushing them out from the locality.

d. The parents were of the view that for their proper handling and normal life, the society needs to be educated as being muslims, our Prophet (S.A.W) instructed for kind treatment with them.

e. The parents wished to see them educated and flourishing as with the help of education, they may be able to have an easy, smooth, acceptable and respectable life.

\section{Trans}

The trans were asked different questions on their issues. Some of the questions were fully answered while some were left in complete and not fully answered.

a. When they were asked why they are in this profession, their answer was very simple and they said, "We know nothing except dancing and merry-making and the society also likes to see us like this". Furthermore, they responded that this was the only source for their survival and square meal. 
b. When they were asked about their choice of profession, the majority were not happy but they had no other choice except this dancing and merry-making.

c. When they were asked, "Why do your parents not own you?". Their responses were mixed and they didn't blame their parents because of their inbuilt love with their parents but they totally blamed the society for their this plight.

d. When they were asked about their not getting education. In response, they cursed and blamed the environment because in school and in class they were all the time under the inviting and amorous gaze from everyone including some of the teachers and their school fellows and even class fellows. Therefore, the environment for their education has never been conducive, they opined.

e. When they were asked about another job for their sustenance, they said yes but added that they were not acceptable to society in any other shape or form than this dancing machine and puppet.

f. In a response to another question, they said that they were totally unacceptable for their brothers and sisters as they also come from the same society like their parents so when parents are not ready to accept them then how can their brothers and sisters would accept and own them.

g. When they were asked about the physical attacks on them. Their response was only reticence.

h. When they were asked that these attacks are only because of their allegedly involvement in adultery and fornication. They said 'to some extent.'

i. When they were asked, "why don't you get the shelter of the umbrella of law, when your life is at stake?". In response to this question they came out with the lame excuses about the inefficiency of legal system in the country.

j. When they were asked that their dancing and other activities are un-islamic and unethical, they blamed the Providence for this and tried to buck the responsibility.

\section{Findings}

1. Laws related to the trans' rights and safety are available in Pakistan.

2. Trans have no proper opportunity of getting education at any level.

3. The society doesn't accept them as normal human beings i.e. either male or female but consider them as a merry-making tool and puppet and segregates them.

4. Trans are involved in fornication and adultery. 
5. Trans' involvement in fornication and adultery bring them under the wrath of the society or their lovers and consequently face some tragic episodes of their life and some are fatal which bring even death for them.

\section{Results}

The responses of all the respondents of the study i.e. lawyers, teachers /school heads, parents of the trans, and trans were obtained with the help of questionnaire and interview and then the responses were interpreted thematically in the light of the given items of the study. The results are alarming as these trans are not accepted in the society. Furthermore, their own parents are not ready to provide them confidence and shelter and help them in facing the odds of the society regarding their life. These trans are not totally innocent like other communities these also have some black sheep who bring destruction upon themselves through cheating when in fornication or amorous relation with other males of the society. They remain in compromising relation with the selected and this poses threat to their life as they do not entertain the others in the same manner. The same is the case with their education as most of them prefer to be in the activities of dancing and merry-making right from the beginning as they involve themselves in the pursuits of education then they will lose their prime time of charm and then they won't be in the position to enjoy the relations like fornication and adultery.

\section{Discussion}

The responses of all the respondents were analyzed and the findings were presented in the light of the questions given in the questionnaire. To some questions the responses of the trans were subjective and they tried to conceal the facts especially those questions which were related to their involvement in the fornication and such like other activities. Due to these strange situation, the society as a whole doesn't accept them and is not accommodative for them and their own character is also responsible for their plight. Furthermore, all the civic rights are available but they hesitate to get the support of law as the law enforcing agencies want to check their activities and for this the trans are not ready. They try to remain in segregation so that they might appeal to the sympathies of the people not only locally but also globally. Education is the key to positive change but the results of the article prove that the trans themselves are not keen in getting education otherwise by proximity with the other members of society will definitely help them in moving easily and respectably in the society. 


\section{Conclusions}

The trans in the Pakhtun belt of District Mardan (KPK) Pakistan have serious problems and issues in their life. These issues and problems thwart them from smooth moving in the society. Education is at the top of these issues and problems. Education has become a prohibited fruit for them as they are not let to complete their education. The trans parents, teachers, and other stake holders are equally responsible for their this deteriorating condition. Some elements among trans are also held responsible for their poor present and horrible future.

\section{Recommendations}

The following recommendations were suggested in the light of the objectives of the study.

1. This is the dire need of the time to create awareness about the status and rights of the trans by seminars, training sessions, and lectures organized by prominent religious scholars and figures of the society. For this purpose the role of the local district government is vital as the representatives are locally elected and they know about the problems of the trans better than anyone else.

2. Education is the basic right of every individual, therefore, the social welfare department may establish shelter homes along with special schools for trans in every district and the school must be comprehensive which may also provide technical education and skill development to the trans so that they may be able to earn their square meal with full dignity and honor.

3. The text book board with the approval of provincial government may include some chapters in the books of Islamiyat, Urdu, English and Social studies regarding the rights and dignity of the trans, so that common man right from the beginning may be able to know about the rights and status of the trans from then these trans will be able to live like normal beings in the society.

4. Those trans who are involved in fornication and such like other activities which are unethical and un-islamic, may be motivated towards chaste and pure life. Different religious groups and scholars may play the pivotal role in this situation.

5. The society as a whole needs to be educated in this situation by the civil societies and organizations and they may educate the parents that these have no hand in their present composition but all this is divinely predestined, because they are not here in the present form by their own choice preached and acted upon in true sense. 
6. The actual Islamic teachings, if, will surely guarantee their honor, security and freedom of all sorts.

\section{References}

Ashraf, G. (2010). Debating the Third Gender. Retrieved from http//www.susan. org.

Buscha, F. and Conte, A. (2010). The impact of truancy on educational attainment during compulsory schooling: a bivariate ordered probit estimator with mixed effects. The Manchester School, Issue 1, Volume 82, pp.103-127.

CSS Forum, (2010). Why is there no status of the Third Gender in Pakistan. Retrieved from http://www.cssforum.com

Hoda , A. (2010). Accepting the Third Gender: Word press.

Kariminia, M.M. (2010). “Taghyir-I Jinsiyat az Manzr-I fiqh va Huquq”. Sex- Change from the Perspective of Fiqh and Law .Qum, Iran:

Nanda, S. (1999). Neither Man nor Woman: The Hijras of India. Belmont, CA:Wadsworth.

Tufail, S. (2006). The Third Gender and Their Status in Pakistan.

Vitale, A. (1997). Notes on Gender Identity Disorder. A Description of the problem.

Whittle, S., Turner, L. and Al-Alami, M. (2007). Engendered Penalties: Transgender and Transsexual People's Experiences of Inequality and Discrimination. London: The Equalities Review.

Wiley, D. and Harnischfeger, A. (1974). Explosion of a myth: Quantity of schooling and exposure to instruction, major educational vehicles. Educational researcher, Issue 4, Volume 3, pp.7-12. 